\title{
Using Aesthetic Response - A Poetic Inquiry to Expand Knowing, Part II: Theoretical Perspectives on Arts-based Research
}

\author{
Anna Gerge ${ }^{1 *}$, Margareta Wärja ${ }^{123}$, Inge Nygaard Pedersen ${ }^{1}$ \\ 1 Doctoral Programme in Music Therapy, Department of Communication and Psychology, Faculty of \\ Humanities, Aalborg University, Denmark \\ 2 Department of Clinical Cancer Epidemiology, Karolinska Institute, Sweden \\ 3 Expressive Arts Institute Stockholm, Sweden \\ *anna@insidan.se
}

Received: 2 September 2016 ; Accepted: 13 February 2017 ; Published: 1 March 2017

\begin{abstract}
Apart from being inspired from both an interpretive and a constructivist tradition, research methods based in aesthetics can thrive from a clear rationale concerning its perceptual building-blocks in both the intersubjective and intra-psychological domains. This article aims to address the complexity of sharing implicit processes and tacit knowledge in the arts-based inquiry. Layers of this inquiry is reflected along with theoretical perspectives of such undertakings. The article also offers a theoretical rationale for why to add and acknowledge important perceptual and affective building blocks in arts-based research (ABR). Through theories from expressive arts therapy, heuristic inquiry, attachment theory and contemporary affective neuroscience some thoughts on the embodied felt sense as a perceptual hub is shared. Based in contemporary attachment theory and psychotherapy research, a rationale is given for why engaging in ABR can offer clinicians and researchers a deepened understanding of the studied phenomena. Our undertakings are presented in part 1 of these two articles. From this embodied perspective, the described arts-based inquiry can be considered as a privileged way to nuance and enlarge understanding in both the intersubjective and intra-psychological domain, which could be particularly helpful to ABR researchers who are informed by a psychodynamic perspective.
\end{abstract}

Keywords: Arts-based research, Arts-based inquiry, Embodied felt sense, Implicit processing, Perceptual and affective building blocks

\section{Theoretical Constructs Underpinning the Rx6 Method}

Contemporary affective neuroscience and attachment research (Cozolino, 2002/2010; Schore, 2012, 2014a, 2014b; Siegel, 1999) give important insight in understanding what might be the bearing agents of image formation (Horowitz, 1983, 2012, 2014). The value of the aesthetic response, as a source of knowledge, cannot be underestimated. Ammaniti and Gallese (2014) noted, "Before and below mind-reading is intercorporeality as the main source of knowledge we directly gather about others" (p.16). They also see this embodiment as a prerequisite for sharing and understanding symbolic representations. Our activated mirror neurons impact our ability to empathize with unconscious states of others. Intercorporeity, rather than the symbolic representation, 
therefore is placed at the core of emotional resonance. Intercorporeity means the experience of being embodied and it is never a private affair, but is always mediated by our continual interactions with other human and nonhuman bodies (Weiss, 1999, p. 5).

Csordas (2008) and Allegranti (2013) pointed out that our existence in relation to others - our inter-subjectivity - is something tangible and bodily. Intersubjectivity is not only declarative or explicit but an analogical map of the other within us, and needs to be read on implicit levels from inside ourselves (Lyons-Ruth et al., 1998). Gerge (2016) exemplified this in her analyses of clinicians' drawings of a worrying or reassuring clinical meeting. The arts-based inquiry offers each and every one of us possibilities to read, by experiencing those maps and work with the embodied aesthetic response (Panhofer et al., 2011), thus allowing a deepened sharing over time and space.

\section{The Aesthetic Response}

The function of an aesthetic response (Robbins, 1971, 1987) is, according to Conrad (2010), to stabilize the brain's semi-randomly generated neural circuits. The neuronal circuits are selectively steadied if they succeed in making sense out of raw sensory input. Under the brain's developmental process, the aesthetic response of humans serves the function of calming the circuits or networks that successfully mediate perception and interpretation. These will become more agile, in the process of making something special. According to Conrad (2010), this is triggered by structures in art and nature, which provoke the sense-making, a deliberate human action.

When discussing the theoretical underpinnings of how self-identity is revised through portraiture in palliative care, Carr (2014) stated:

The relationship between the 'container' and the 'contained' is an intersubjective one, and this combined experience becomes in the portrait a concrete, sensory and symbolic form (Langer, 1953), offering a unique way to hold, contain and safeguard this attuned experience. (pp. 57-58)

Carr's (2014) clinical standpoint is based in the tradition focused on the 'art' within art therapy (Allen, 1992, 2001; Malchiodi, 1999; McNiff, 1986), thus a therapeutic endeavour closely connected with ABR.

The artistic expressions constitute in therapy an expanded field, in which new structuring of the inner world is possible. This leads to, that conflict-loaded material, i.e. overwhelming affect and negatively charged images, can be externalized, perceived and processed. (Gerge, 2010, p. 69)

This endeavour can be as valuable in research as in clinical work. The aesthetic sensibility needed in arts-based inquiry (Viega, 2016a) can be considered especially wellsuited for professionals trained in the creative arts therapies, for examples see (Gerge, 2016; Gerge, Wärja, \& Pedersen, 2017).

In Phenomenology of Perception Merleau-Ponty (1963) described the body's encounter with the phenomenon, as it is through the body we understand the world (Bullington, 1999). Damasio $(1995,1999)$ stated that a thought always is a description of an embodied state. By using our theory of mind (Frith \& Frith, 1999) and our embodied empathy (Rothschild, 2000) we can imagine ourselves as the other and authentically meet the other; an important prerequisite for change-inducing meetings in psychotherapy (Gerge, 2011, 2015) and research (Gerge, 2016). This capacity rests on an embodied felt-sense experience (Gendlin 1964, 1978), which is the core of the aesthetic response, empathy, image formation, and at its end-point, an acknowledged perception. We think such a standpoint is valuable also in research.

\section{The Experience of the Felt Sense}

Gendlin (1978) developed Merleau-Ponty's $(1963,1973)$ ideas to show how interactions are more fundamental than perception. The bodily experience was essential to the work of Merleau-Ponty, who referred to the internal total awareness as body 
schema (1963, p. 113-114); see definition at the end of the article. This embodied felt sense is supposed to ground our conscious awareness, in line with Damasio's (1995, 1999) notion - a thought is an ongoing description of a state in the body. In everyday language, we lack words to name these crucial processes, however in the therapeutic practice of Focusing (Gendlin, 1978), it is described as an embodied tacit knowledge. This is a special kind of internal bodily awareness, a body-sense focused on meaning making, which offers a potential research tool for collecting and describing data from non-verbal sources. What is described can further on be analysed.

\section{Attachment Theory and Contemporary Neuroscience in ABR}

The capacity of being together is mediated over our mirror-neurons (Rizzolatti, Fadiga, Fogassi, \& Gallese, 1999). Our brains are in Gallese's words "we-centric" (Gallese, 2009). Our capacity to resonate - a necessary prerequisite for reasoning - can be used as a vehicle for deepening our understanding of the topics of interest we want to study. These processes will always be partly preverbal.

Recently, McCaffrey \& Edwards (2015) discussed ABR as non-narrative, "as many processes and products in arts creation transcend literal meanings" (p. 516). We fully agree with their reflection, though we think that the concept non-narrative has to be problematized, as narrate, apart from referring to speech and writing can be to tell by means of images. Our conscious awareness resides in larger orders of affective and cognitive narratives, which are based in experiential implicit bodily processes referred to as the "neuronal architecture which supports consciousness" by Damasio (1999, p. 15). In 1992, Daniel Stern introduced the term "proto-narrative envelope" ( pp. 291-295). This envelope he stated, contains experiences organized within the structure of a narrative and are built from the child's experiences of happened or imagined events, as these are unfolding. However, it refers to a story without words or symbols, a plot visible only through the perceptual, affective, and motoric strategies to which it gives rise. Stern (1995) stressed how early experiences of mother-child interactions "have a beginning, a middle, and an end and a line of dramatic tension; they are tiny narratives ... 'proto-narrative envelopes'" (Stern, 2002, p. 6). In 2004, Stern changed the concept proto-narrative envelope to "lived story" (Stern, 2004, p. xiii). This concept is related to an emotional narrative that is felt rather than told as a cognitively constructed story for both infants and adults (Stern, 2004) and is a prerequisite for a moment of meeting, (see further definitions at the end of the article). The concept lived story and our contemporary neuro-affective understanding of human recognition processes (Gallese, 2009; Hass-Cohen \& Findlay, 2015), make statements such as the arts-based inquiry is nonverbal or non-narrative highly questionable. On the other hand, they point to possible ways in which music, experienced on preverbal levels can give us images and evoke stories (Stern, 2000, 2004, 2010). From this perspective arts/artifacts can be seen as frozen moments in time, even if the person who has produced the artifact is not present.

As shown in the method description of part 1, (Gerge et al., 2017), we want to highlight the short time frame of a half of a minute, to be used when becoming touched and initiating an aesthetic response (even though conducting an artwork or performance might take somewhat or much longer time). An extended moment of meeting will not be longer than 30 seconds according to Stern (2004). We propose that this limited time frame is an essential building block of the felt-sense experience. It is a prerequisite for the aesthetic response, even at times when the final arts-based inquiry involves composing a musical symphony or creating a mural painting (taking months to prepare).

We hypothesize that the similar processes as in attachment modulation are active also when we relate to an artifact, for examples see part 1 (Gerge et al., 2017), where poetic responses were achieved. In poetic transcription (Faulkner, 2009; Furman, 2006; Leavy, 2015) the inquiry is derived from a grounded theory perspective, where selected words and phrases from the informants become building blocks of the poems conducted. In poetic transcription, according to Faulkner (2009), notes of written state- 
ments of the informants are directly cited, and then put into a structure chosen by the researcher. In our work, poetic statements were created as aesthetic responses in line with the primary signification of the word poetry (poiesis) meaning "to create". When working with the aesthetic response in an arts-based inquiry, we consider it possible that the implicit information, the proto-narrative in the art piece, can be listened to in a similar way as when one is present with another human being. In this way, ABR has the potential to resemble the regulatory processes of the early dyad where the concept moment of meeting (MoM) is crucial (Sander, 2002; Stern, 2004). These time-framed important building blocks of early development and attachment continues to be active in human perception all through our lives. As adults we also form lived stories in our on-going endeavour to understand the world and ourselves. Organisation of meaning is implicit as Lyons-Ruth (1999) stated. She highlighted that we do "not require reflective thought or verbalization to be known" (p. 578).

The process of being known, or feeling felt, is well described in attachment research (Schore, 1994, 2003a, 2003b, 2003c, 2003d; Sander, 2002; Stern, 2004). We consider these communicative aspects of attachment research also relevant in the experiential being with in relating to an art piece in art/creative arts therapy or ABR. The processes that build the experience of being known are scientifically validated in recent neuroaffective research on mirroring (Ammaniti \& Gallese, 2014; Gallese, 2009) and intersubjectivity (Siegel, 2010).

Sander (2002) highlighted the communicative aspects of affects and affect regulation. In line with Schore (1994), he described affects as observable states and thus highly communicative. Such perspective is emphasized in contemporary social psychological research (Wetherell, 2015). Daniel Stern (1985) developed Silvan T. Tomkins' affect theory $(1962,1963)$ and added the concept vitality affects, where the musicality and dynamic quality of being together (and being with emotions and affects) and relate on preverbal levels as building blocks of perception were highlighted (Ammaniti \& Ferrari, 2013; Stern, 1985, 1994, 2000). Building on nonlinear systems theory, Sander (2002) and Stern $(1985,2010)$ developed our understanding on how human beings can fit together. By accurate preparatory attunement (recognition processes) special moments of shared experience (MoM) can generate strong feelings of connection between people. These processes are well described in psychotherapy research (Hughes, 2007), including music therapy (Blom, 2014; Coomans, 2016) and art therapy (HassCohen \& Findlay, 2015). Also, when moving into a relationship with an artifact, we can open up to a transformative meeting. By using the timeframe of an extended MoM in profound meetings with other human beings and/or their artifacts, we consider that a certain rigor can be brought into the multi-layered themes of implicit processing, which will be activated every time our attachment system is activated (Trevarthen \& Aiken, 2001). This processing will also be activated every time we allow ourselves to be touched, which is an essential part of the arts-based inquiry.

Research on attachment points to the role of shared interconnectivity described by (Gallese \& Ferri, 2014; Bowlby, 1968; Gaensbauer, 2016; Schore, 2003d, 2009; Siegel, 1999) as a prerequisite for development, empathy, and mentalization (Fonagy \& Luyten, 2015). Kenny $(1989,2006)$ described an intuitive level of togetherness that encompasses therapist and client in clinical work. Kenny's (2006) meta-theory on what might happen in the encounter between client and therapist is highly relevant for ABR. She highlighted the need for an existential phenomenology; immersion, tacit knowing, and intentional verification of the felt sense experience (Douglass \& Moustakas, 1985) to make sense of what one experiences. This neatly fits into contemporary attachment research (Gallese 2009; Narvaez et al., 2013). Kenny $(2006,2015)$ labelled the process of making sense as an act of creativity, empathy, and letting oneself be touched by the other/the other's expression, and what might be called existential beauty. She also stated "Perhaps my words will never be able to describe the beauty of these moment" (Kenny, 2006, p. 192), thus addressing the implicit nature of togetherness. This is in line with Stern's reflection "one can not get to the lived experience and stay there while talking about it" (2004, p.xiii). But of course we ought to try, and we are genetically 
hard-wired to make sense of, and share implicit information, both for our survival as individuals and as species.

\section{Art as "Making Special" and Implicit Processing}

Dissanayake $(1988,2000,2003)$ argued that art serves as the key social role of "making special" when experiencing phenomena and thus can help us both invest and research certain phenomena with special significance. In Jungian psychology this process is described as crystallization (Henderson, 1964). Knill, Barba, and Fuchs (1995) spoke of crystallization as "the basic human need to crystallize psychic material; that is, to move toward optimal clarity and precision of feeling and thought" (p. 30). This is a key function of art-making and art experiencing and can be considered an important principle when making sense of information in the aesthetic domain. In this way the artistic process has great similarities with the pragmatic and eclectic approach to qualitative research (Gordon, 1999; Leavy, 2015).

According to Faulkner (2005), cited in Leavy (2015), The poetic criteria related to qualitative and artistic criteria are; "artistic concentration, embodied experience, discovery/surprise, conditional, narrative truth, and transformation" (p. 97). In line with this, Leavy (2015, citing Richardson, 1997 and Pelias, 2011) put forward what we might speak of crystallization instead of triangulation. She continued, "poetry is both a style of representation as well as a vehicle through which the research community can engage in larger questions about the nature of social research, truth and knowledge" (p. 97). In this way the arts-based research or inquiry can help us grasp the essence of the studied phenomena and experiences. It can add resonance to reason. The ABR potential experience of resonance and touching "essence" supposedly adds to the experience of deepened sharing. This encompasses also to lower the guard, to make oneself vulnerable, and open to a potential experience of awe (Gerge, 2016).

\section{Concluding Words}

Our aim in this paper was to describe a vital procedure including a timeframe in line with contemporary theory of the phenomenon of the moment of meeting (MoM) (Sander, 2002; Stern, 2004). The use of the method and its six steps; relate, resonate, respond, reflect, react, and results was exemplified in "Using Aesthetic Response, a Poetic Inquiry to Expand Knowing. Part I: The Rx6-Method" (Gerge et al., 2017). The Rx6 method is grounded on a theoretical framework of inter-subjectivity and implicit processing, in line with relational psychodynamics. Engaging in ABR can offer clinicians and researchers of all orientations a deepened, expanded, and embodied understanding of the studied phenomena. This can be considered a prerequisite for heightened empathy. We consider the ABR-approach especially important when working with the indwelling procedures of implicit processing, eg., when using tacit knowledge (Polanyi, 1958), in research and psychotherapy.

We hope that the MoM can be considered a perceptual tool to make sense of what we encounter in the experience of being with another human being, and/or with her/ his artifacts, or - when being in an I-Thou relation (Buber, 1962/1993). The MoM theory helped us conceptualize the perceptual building blocks of coming close to another human being. This understanding is necessary in attachment work (Schore, 1994; 2003a, 2003b, 2003c; Trevarthen, 1993), which is well documented and implemented in psychotherapy with psychodynamic orientation (Schore, 2003d; Terr, 2003), music therapy (Blom, 2014; Coomans, 2016), and art therapy (Carr, 2014). Though we propose that this approach can be of value for clinicians and researchers of other orientations as well.

The theory of MoM, (Sander, 2002; Stern, 2004) and consciously working with intermodal transfer can build loops of ABR over an extended time (days, weeks and months) (Gerge, 2016). We regard the MoM as a grounding basic beat - a pulse of perception - a building block of the flow of human experience in processes where the medium is the message (Lyons-Ruth, 1999); as in experiential psychotherapy (Gerge, 
2015) or ABR (Gerge, 2016; Gerge et al., 2017). Although Ledger and McCaffrey (2015) argued that it is too early to create definitions as these might limit the possibilities for innovations that ABR might bring to music therapy (p. 453), we consider the structure, including the time frame suggested here, as an important reflective tool, both as a method, and for methodologies "steeped in aesthetics" (Viega, 2016b, p. 5). In putting focus on perception, as described in attachment research (Sander, 2002, Stern, 2004; Narvaez et al., 2013), contemporary affective neuroscience (Ammaniti \& Gallese, 2014) and clinical work, (Hass-Cohen \& Carr, 2008; Hughes, 2007), we can begin to structure ABR. From a solid hub of theoretical frameworks (with spokes in all directions), various modalities and art disciplines can radiate. From such a hub, seen as an "orienting lens" for understanding a phenomenon (Creswell, 2009; Shannon-Baker, 2015), a variety of sound research and innovative applications might rise. In this way ancient roots of creativity can meet and be nourished from heuristic research perspectives (Moustakas, 1990, 1994), expressive arts therapy (Estrella, 2005; Levine \& Levine, 1998, 2005; Richardson, 2016) and attachment theory, including the theories of the lived story (Stern, 2004), and the theory of MoM (Sander, 2002; Stern, 2004). This will further enrich qualitative research, the discursive practice (Wetherell, 2015), and psychotherapy research including the arts-based therapies.

To conclude, first we propose that clinicians, conducting clinical research, scholars in psychology and health care research, including rehabilitation medicine, consider using ABR as a means to expand their understanding. Second, these processes will deepen their compassion for and understanding of their research participants and their processes of change. With Chenail (2008) we answered the question concerning ABR "But is it research?" with a firm YES.

\section{Glossary of Terms}

Body schema: Merleau-Ponty (1963, p. 113-114) referred to the internal total awareness as body schema. This embodied awareness is conceptualised as an on going bodily interaction that opens us to a sense of the world beyond what we conventionally call perception. The body-sense can encompass perceptions and emotions but also memories of past situations and options of what to do next.

Present moment or now moment: Daniel Stern (2004) defined the "present moment" as a lived story with a beginning and an end, intentional characters, together with a "temporal contour along which the experience forms during its unfolding" (p. 219). The present moment is defined as lived through as it unfolds and is not distanced by language or abstract explanation from those experiencing it. The now moment consists of an emerging interpersonal process that is unpredictable-hence "sloppy," consisting of the present moment in life-as-lived, which Stern generalizes from attachment research to psychotherapy. The concept is elaborated from The Interpersonal World of the Infant (Stern, 1985).

Moment of meeting: The now moment is often followed by a moment of meeting (Stern, 2004). When this occurs, new ways of being-with-the-other unfolds through the offered time-framed togetherness, where we can "read in the behavior of the other a reflection of their own experience" (p. 220-221). This leads to the possibility of events becoming intersubjectively conscious, and further on verbalized and narrated experiences.

\section{References}

Allegranti, B. (2013). The politics of becoming bodies: Sex, gender and intersubjectivity in motion. The Arts in Psychotherapy, 40, 394-403, https://doi.org/10.1016/j.aip.2013.05.017.

Allen, P. B. (1992). Artist-in-residence: An alternative to "clinification" for art therapists. Art Therapy, 9(1), 22-29, https://doi.org/10.1080/07421656.1992.10758933. 
Allen, P. (2001). The open studio process as a way to practice art therapy. In J. Rubin (Ed.), Approaches to art therapy: Theory and technique (2nd ed.). New York \& London: BrunnerRoutledge.

Ammaniti, M., \& Ferrari, P. (2013). Vitality affects in Daniel Stern's thinking-A psychological and neurobiological perspective. Infant Mental Health Journal, 34, 367-375, https://doi.org/ 10.1002/imhj.21405.

Ammaniti, M., \& Gallese, V. (2014). The birth of intersubjectivity: Psychodynamics, neurobiology, and the self. New York: WW Norton \& Co.

Blom, K. M. (2014). Experiences of transcendence and the process of surrender in guided imagery and music (GIM): Development of new understanding through theories of intersubjectivity and change in psychotherapy. (Unpublished doctoral dissertation). Aalborg Unitersity, Aalborg, Denmark. Reterived from http://vbn.aau.dk/da/persons/katarinamaartenson-blom(498eb6de-91be-4a53-a814-77d88d35f0a6).html

Bowlby, J. (1968). Attachment: Attachment and loss volume one. New York, NY: Basic Books.

Buber, M. (1962/1993). Dialogens väsen : traktat om det dialogiska livet (Sällström, P., Trans.). Ludvika, Sweden: Dualis.

Bullington, J. (1999). The mysterious life of the body: A new look at psychosomatics. Stockholm: Almqvist \& Wiksell International.

Carr, S. M. D. (2014). Revisioning self-identity: The role of portraits, neuroscience and the art therapist's 'third hand'. International Journal of Art Therapy, 19(2), 54-70.

Chenail, R. J. (2008). "But is it research?”: A Review of Patricia Leavy's method meets art: Arts-based research practice. The Weekly Qualitative Report, 1(2), 7-12.

Coomans, A. (2016). Moments of resonance in musical improvisation with persons with severe dementia: An interpretative phenomenological study. Aalborg, Denmark: Aalborg University. http://vbn.aau.dk/da/persons/anke-coomans(f330f53b-145a-4117-bf3bd95f509aaaef).html.

Conrad, D. (2010). A functional model of the aesthetic response. Contemporary Aesthetics, 8, http://www.contempaesthetics.org/newvolume/pages/article.php?articleID $=581$.

Cozolino, L. (2002/2010). The neuroscience of psychotherapy. Building and rebuilding the human brain. New York, NY: Norton.

Creswell, J. W. (2009). Research design: Qualitative, quantitative and mixed methods approaches (3rd ed.). Thousand Oaks, CA: Sage.

Csordas, T. J. (2008). Intersubjectivity and intercorporeality. Subjectivity, 22(1), 110-121, https://doi.org/10.1057/sub.2008.5.

Damasio, A. (1995). Descartes' error: Emotion, reason, and the human brain. New York, NY: Penguin Books.

Damasio, A. (1999). The Feeling of what happens: Body and emotion in the making of consiousness. New York, NY: Harcourt.

Dissanayake, E. (1988). What is art for? Seattle, WA: University of Washington Press.

Dissanayake, E. (2000). Art and intimacy. Seattle, WA: University of Washington Press.

Dissanayake, E. (2003). The core of art : Making special. Canadian Journal of the Association for Curriculum Studies, 1(2), 13-38.

Douglass, B., \& Moustakas, C. (1985). Heuristic inquiry: The internal search to know. Journal of Humanistic Psychology, 25(3), 39-55, https://doi.org/10.1177/0022167885253004.

Estrella, K. (2005). Expressive therapy: An integrated arts approach. In C. A. Malchiodi (Ed.), Expressive therapies (pp. 183-209). New York: Guilford Press.

Faulkner, S. L. (2005). Method: Six poems. Qualitative Inquiry, 11(6), 941-949, https://doi.org/ $10.1177 / 1077800405276813$.

Faulkner, S. L. (2009). Poetry as method: Reporting research through verse. Walnut Creek, CA: Left Coast Press. 
Fonagy, P., \& Luyten, P. (2015). A multilevel perspective on the development of borderline personality disorder. In D. Cicchetti (Ed.). In D. Cicchetti (Ed.), Developmental psychopathology. Vol 3: Maladaptation and psychopathology (3rd ed., pp. 726-792). New York, NY: John Wiley \& Sons.

Frith, C. D., \& Frith, U. (1999). Interacting minds--a biological basis. Science, 286(5445), 1692-1695, https://doi.org/10.1126/science.286.5445.1692.

Furman, R. (2006). Poetic Forms and Structures in Qualitative Health Research. Qualitative health research, 16(4), 560-566, https://doi.org/10.1177/1049732306286819.

Gaensbauer, T. J. (2016). Moments of meeting: The relevance of Lou Sander's and Dan Stern's conceptual framework for understanding the development of pathological social relatedness. Infant Mental Health Journal, 37(2), 172-188, http://dx.doi.org/10.1002/ imhj.21555.

Gallese, V. (2009). Mirror neurons, embodied simulation, and the neural basis of social identification. Psychoanalytic Dialogues, 19(5), 519-536, http://dx.doi.org/10.1080/ 10481880903231910.

Gallese, V., \& Ferri, F. (2014). Psychopathology and the bodily self: The case of schizophrenia. 47(6), 357-364, https://doi.org/10.1159/000365638.

Gendlin, E. T. (1964). A theory of personality change. In P. Worchel \& D. Byrne (Eds.), Personality change (pp. 100-148). New York: John Wiley and Sons.

Gendlin, E. (1978). Focusing. NY: Everest House.

Gerge, A. (2010). Chapters 1-13. In A. Gerge (Ed.), Kreativt gestaltande psykoterapi (pp. 16-116). Stockholm, Sweden: Insidan. [Creative psychotherapy].

Gerge, A. (Ed.). (2011). Med empatin bevarad: varför handledning är nödvändig [With empathy preserved: why supervision is necessary]. Stockholm: Insidan.

Gerge, A. (Ed.). (2015). Psykoterapi som hjälper : metoder för vården [Psychotherapy that helps: methods of caring]. Stockholm: Insidan.

Gerge, A. (2016). Answering from the center: Arts-based research for knowing more. Manuscript submitted for publication.

Gerge, A., Wärja, M., \& Pedersen, I. N. (2017). Using aesthetic response - A poetic inquiry to expand knowing, part I: The Rx6-Method. Voices: A World Forum for Music Therapy, 17(1), http://dx.doi.org/10.15845/voices.v17i1.890.

Gordon, W. (1999). Good thinking - A guide to qualitative research. London, England: NTC Publications.

Hass-Cohen, N., \& Carr, R. (2008). Art therapy and clinical neuroscience. England: Jessica Kingsley.

Hass-Cohen, N., \& Finlay, J. C. (2015). Art therapy and the neuroscience of relationships, creativity, \& resilience. New York, NY: Norton.

Henderson, J. (1964). Ancient myths and modern man. In C. G. Jung (Ed.), Man and his symbols. New York, NY: Bantam Books.

Horowitz, M. (1983). Image formation and psychotherapy. New York, NY: Jason Aronson.

Horowitz, M. (2012). Uncovering the unconscious: A course in self transformation. CreateSpace.

Horowitz, M. (2014). Identity and the new psychoanalytic explorations of self-organization. USA: Horowitz.

Hughes, P. (2007). Attachment-focused family therapy. New York, NY: Norton.

Kenny, C. (1989). The field of play: A guide for the theory and practice of music therapy. Atascadero, CA: Ridgeview Publishing Co.

Kenny, C. (2006). Music and life in the field of play: An anthology. Gilsum, NH: Barcelona Publishers.

Kenny, C. (2015). Performing theory: Playing in the music therapy discourse. Journal of Music Therapy, 52, 457-486, http://dx.doi.org/10.1093/jmt/thv019.

Knill, P., Barba, H., \& Fuchs, M. (1995). Minstrels of the soul. Toronto: Palmerston. 
Leavy, P. (2015). Method meets art: Arts-based research practice (2nd ed.). New York, NY: Guilford Press.

Ledger, A., \& McCaffrey, T. (2015). Performative, arts-based, or arts-informed? Reflections on the development of arts-based research in music therapy. Journal of Music Therapy, 52(4), 441-456, https://doi.org/10.1093/jmt/thv013.

Levine, E., \& Levine, S. K. (Eds.). (1998). Foundations of expressive arts therapy: Theoretical and clinical perspectives. London, England: Jessica Kingsley Publishers.

Levine, K., \& Levine, E. (2005). Principles and practice of expressive arts therapy. Towards a therapeutic aesthetics. London, England: Jessica Kingsley Publishers.

Lyons-Ruth, K. (1999). The two-person unconscious: Intersubjective dialogue, enactive relational representation, and the emergence of new forms of relational organization. Psychoanalytic Inquiry, 19, 576-617, https://doi.org/10.1080/07351699909534267.

Lyons-Ruth, K., Bruschweiler-Stern, N., Harrison, A. M., Morgan, A. C., Nahum, J. P., Sander, L., Stern, D. N., \& Tronick, E. Z. (1998). Implicit relational knowing: Its role in development and psychoanalytic treatment. Infant Mental Health Journal, 19, 282-289, http://dx.doi.org/10.1002/(SICI)1097-0355(199823)19:3<282::AID-IMHJ3 > 3.0.CO;2-O.

Malchiodi, C. (1999). Medical art therapy with adults. London, England: Jessica Kingsley Publishers.

McCaffrey, T., \& Edwards, J. (2015). Meeting art with art: Arts based methods enhance researcher reflexivity in research with mental health service users. Journal of Music Therapy, 52, 515-532, https://doi.org/10.1093/jmt/thv016.

McNiff, S. (1986). Freedom of research and artistic inquiry. Arts in Psychotherapy, 13, 279-284, https://doi.org/10.1016/0197-4556\%2886\%2990028-6.

Merleau-Ponty, M. (1963). The phenomenology of perception. Abingdon, England: Routledge. Original work published 1945.

Merleau-Ponty, M. (1973). Consciousness and the acquisition of language (Silverman, H. J., Trans.). Evanston, IL: Northwestern University Press. Original work published 1949.

Moustakas, C. (1990). Heuristic research: Design, methodology, and applications. Thousand Oaks, CA: Sage. https://doi.org/10.4135/9781412995641.

Moustakas, C. (1994). Phenomenological research methods. Oaks, CA: Sage. https://doi.org/ 10.4135/9781412995658.

Narvaez, D., Panksepp, J., Schore, A. N., \& Gleason, T. R. (Eds.). (2013). Evolution, early experience and human development : From research to practice and policy. Oxford, England: Oxford University Press.

Panhofer, H., Payne, H., Meekums, B., \& Parke, T. (2011). Dancing, moving and writing in clinical supervision? Employing embodied practices in psychotherapy supervision. The Arts in Psychotherapy, 38(1), 9-16, http://dx.doi.org/10.1016/j.aip.2010.10.001.

Polanyi, M. (1958/1998). Personal knowledge. Towards a post critical philosophy. London, England: Routledge.

Richardson, C. (2016). Expressive arts therapy or traumatized children and adolescents: A four phase model. New York, NY: Routledge.

Rizzolatti, G., Fadiga, L., Fogassi, L., \& Gallese, V. (1999). Resonance behaviors and mirror neurons. Archives of Italian biology, 137(2-3), 85-100.

Robbins, A. (1971/1974). The use of imagery by the art therapist in creative dialogue. Arts in Psychotherapy, 2, 80-85.

Robbins, A. (1987). The artist as therapist. New York, NY: Human Sciences.

Rothschild, B. (2000). The body remembers: The psychophysiology of trauma and trauma treatment. New York, NY: W.W. Norton.

Sander, L. W. (2002). Thinking differently: Principles of process in living systems and the specificity of being known. Psychoanalytic Dialogues, 12, 11-42, https://doi.org/10.1080/ 10481881209348652. 
Schore, A. N. (1994). Affect regulation and the origin of the self: The neurobiology of emotional development. Mahwah, NJ: Erlbaum.

Schore, A. N. (2003a). Affect regulation and the origin of the self. Mahwah, NJ: Earlbaum.

Schore, A. N. (2003b). Affect dysregulation and disorders of the self. New York, NY: Norton.

Schore, A. N. (2003c). Affect regulation and the repair of the self. New York: Norton.

Schore, A. N. (2003d). The seventh annual John Bowlby memorial lecture minds in the making: attachment, the self-organizing brain, and developmentally-oriented psychoanalytic psychotherapy. In J. Corrigall \& H. Wilkinson (Eds.), Revolutionary connections psychotherapy and neuroscience. New York: Karnac.

Schore, A. N. (2009). Attachment trauma and the developing right brain: Origins of pathological dissociation. In P. F. Dell \& J. A. O’Neil (Eds.), Dissociation and the dissociative Disorders: DSM-5 and Beyond. New York, NY: Routledge.

Schore, A. N. (2012). The science of the art of psychotherapy. York, NY: Norton.

Schore, A. (2014a). Neurobiologically informed trauma therapy with children and adolescents. New York: Norton.

Schore, A. (2014b). The right brain is dominant in psychotherapy. Psychotherapy, 51, 388-397, http://dx.doi.org/10.1037/a0037083.

Shannon-Baker, P. (2015). Making paradigms meaningful in mixed methods research. Journal of Mixed Methods Research, 10, 1-16, http://dx.doi.org/10.1177/1558689815575861.

Siegel, D. (1999). The developing mind: Toward a neurobiology of interpersonal experience. New York, NY: Guilford.

Siegel, D. (2010). Mindsight: The new science of personal transformation. New York, NY: Norton.

Stern, D. N. (1985). The interpersonal world of the infant: A view from psychoanalysis and developmental psychology. New York, NY: Basic Books.

Stern, D. N. (1992). The 'pre-narrative envelope': An alternative view of 'unconscious phantasy' in infancy. Bulletine of the Anna Freud Centre, 15, 291-318.

Stern, D. N. (1994). One way to develop a clinically relevant baby. Infant Mental Health Journal, 15, 9-25, https://doi.org/10.1002/1097-0355\%28199421\%2915:1\%3C9::AIDIMHJ2280150103\%3E3.0.CO;2-V.

Stern, D. N. (1995). The motherhood constellation. New York, NY: Basic Books.

Stern, D. (2000). Ett litet barns dagbok [Diary of a baby]. Sweden: Natur och Kultur.

Stern, D. (2002). The first relationship: Infant and mother. Cambridge, MA: Harvard University Press.

Stern, D. (2004). The present moment in psychotherapy and everyday life. New York, NY: Basic Books.

Stern, D. (2010). Forms of vitality: Exploring dynamic experience in psychology, the arts, psychotherapy, and development. Oxford, England: Oxford University Press.

Terr, L. C. (2003). Wild child: How three principles of healing organized 12 years of psychotherapy. Journal of American Academy of Child \& Adolescent Psychiatry, 42, 1401-1409, https://doi.org/10.1097/00004583-200312000-00006.

Tomkins, S. (1962). Affect Imagery Consciousness: Volume I: The Positive Affects. New York, NY: Springer Publishing Company.

Tomkins, S. (1963). Affect Imagery Consciousness: Volume II: The Negative Affects. New York, NY: Springer Publishing Company.

Trevarthen, C. (1993). Brain, science and the human spirit. In J. B. Ashbrook (Ed.), Brain, culture and the human spirit (pp. 129-181). Lanham, MD: University Press of America.

Trevarthen, C., \& Aitken, K. J. (2001). Infant intersubjectivity: Research, theory, and clinical applications. Journal of Child Psychology and Psychiatry, 42, 3-48, https://doi.org/10.1111/ 1469-7610.00701.

Viega, M. (2016a). Aesthetic sense and sensibility: Arts-based research and music therapy. Music Therapy Perspectives, 34(1), 1-3, http://dx.doi.org/10.1093/mtp/miw010. 
Viega, M. (2016b). Science as art: Axiology as a central component in methodology and evaluation of arts-based research (ABR). Music Therapy Perspectives, 34, 4-13, http://dx.doi.org/10.1093/mtp/miv043.

Weiss, G. (1999). Body images: Embodiment as intercorporeality. New York: Routledge.

Wetherell, M. (2015). Trends in the Turn to Affect: A Social Psychological Critique. Body \& Society, 21(2), 139-166, http://dx.doi.org/10.1177/1357034X14539020. 